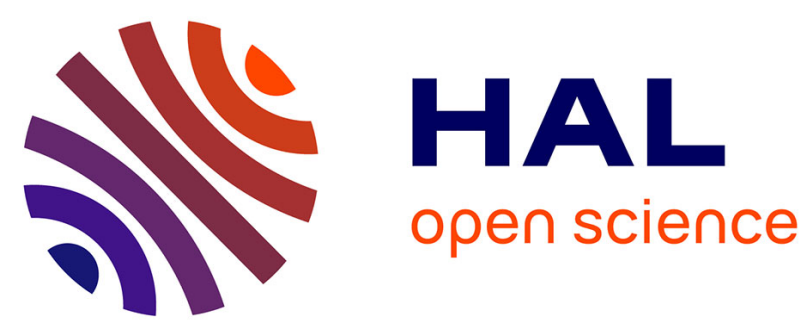

\title{
The Use of STM for Investigation of Surface Relief in Respect to Tribologic Properties of DLC Coatings
}

V. Arbuzov, V. Vykhodets, I. Trakhtenberg, A. Davletshin, O. Bakunin, S. Plotnikov, J. R. Lee, S. Kim, B. Chung

\section{- To cite this version:}

V. Arbuzov, V. Vykhodets, I. Trakhtenberg, A. Davletshin, O. Bakunin, et al.. The Use of STM for Investigation of Surface Relief in Respect to Tribologic Properties of DLC Coatings. Journal de Physique IV Proceedings, 1996, 06 (C5), pp.C5-185-C5-188. 10.1051/jp4:1996530 jpa-00254409

HAL Id: jpa-00254409

https://hal.science/jpa-00254409

Submitted on 1 Jan 1996

HAL is a multi-disciplinary open access archive for the deposit and dissemination of scientific research documents, whether they are published or not. The documents may come from teaching and research institutions in France or abroad, or from public or private research centers.
L'archive ouverte pluridisciplinaire HAL, est destinée au dépôt et à la diffusion de documents scientifiques de niveau recherche, publiés ou non, émanant des établissements d'enseignement et de recherche français ou étrangers, des laboratoires publics ou privés. 


\title{
The Use of STM for Investigation of Surface Relief in Respect to Tribologic Properties of DLC Coatings
}

\author{
V.L. Arbuzov, V.B. Vykhodets, I.Sh. Trakhtenberg, A.E. Davletshin, O.M. Bakunin, S.A. Plotnikov, \\ J.H. Lee*, S.J. Kim* and B.S. Chung* \\ Institute of Metal Physics, Ural Division of Russian Academy of Sciences, GSP 170, Kovalevskaya St. 18, \\ 620219 Ekaterinburg, Russia \\ * Samsung Electronics Co. LTD, Suwon City, Korea
}

\begin{abstract}
The surface relief is one of the main factors defining the trybological properties of friction pairs, especially in the case of diamond and diamond like carbon (DLC) coatings. Even such thin as $10-100 \mathrm{~nm}$ coating can considerably increase the wear resistance and drastically reduce the friction coefficient of friction pairs. The most convenient techniques for investigation microrelief effect on trybologyc properties of thin films seems to be the scanning tunneling microscopy (STM). The microrelief was changed by surface bombardment with $1 \mathrm{keV}$ ions of $\mathrm{O}$, Ar and $\mathrm{N}$. The friction coefficients was found to depend upon ion bombardment time and the minimal value could be achieved. The STM studies showed that namely at this time the surface relief was the most smooth. For the coatings in the initial state the surface relief was about $15-20 \mathrm{~nm}$ and in the state with minimal friction coefficient - about $1.5-3 \mathrm{~nm}$.
\end{abstract}

\section{INTRODUCTION}

A high hardness, a great wear resistance and low friction coefficients favor application of diamond and diamond-like carbon (DLC) coatings in friction pairs. Previous investigations showed that friction coefficients lower than 0.05 can be obtained depending on the DLC chemical composition (determined by the DLC deposition method) and particular environment [1-5].

It was demonstrated [5] that wear rate and starting friction coefficients of the "diamond pin - diamond film" pair grow with increasing roughness of the surface. As the films get worn, friction coefficients decrease sharply and stabilize at a level of 0.05 irrespective of the initial relief.

The influence of the surface relief of DLC (2-4 $\mu \mathrm{m}$ thick) on tribologic properties has been analyzed in detail elsewhere [7]. It was shown that when the surfaces were etched with oxygen ions, both the average surface roughness and friction coefficients on steel decreased, passed through a minimum, and increased again.

Among other promising applications, diamond and DLC coating can be used to improve wear resistance and to lower friction coefficients in magnetic recording systems, specifically video recording equipment. Here an important point is that the coating thickness is strictly limited to $50 \mathrm{~nm}$ in order to provide a sufficient signal and a high recording density. For this reason the surface relief is much less developed than that of the coatings studied in Refs. [5, 7]. For the same reason a significant role is attached to the relief of the working surface of a video head, on which the DLC is deposited. The above factors determined the goal of this study: to investigate how DLC deposition conditions influence tribologic properties of DLC's and performance of video heads. Scanning tunneling microscopy was used to examine the surface relief. 


\section{EXPERIMENT}

The experimental sputtering plant had three ion sources: an ion gun for preliminary cleaning of the surface by argon bombardment; a source for deposition of a metal sublayer; and a pulse arc source for sputtering of DLC's from a graphite target [6]. The same ion gun was applied to change the surface relief by bombardment with $1 \mathrm{keV}$ ions of oxygen, argon or nitrogen.

Rutherford Backscattering and Nuclear Reaction Analysis methods were used to measure thickness of the metal sublayer and DLC respectively. The sublayer thickness was $10 \%$ of the DLC thickness.

Friction coefficients of the DLC on steel were determined at a load of $100 \mathrm{~g}$ using a "pin on disk" configuration. A DLC $100 \mathrm{~nm}$ thick deposited on a glass substrate was tested. The indenter was a ball, $3 \mathrm{~mm}$ in diameter, wich was made of the ØÕ-15 steel.

Thickness of DLC deposited on video heads (Samsung Electronics Co.) was 20-50 $\mathrm{nm}$. The quality of the video heads was characterized by the following test parameters: 1) wear resistance, which means lowering of the video signal level after operation with a special abrasive tape for a certain period of time, and 2) clogging time, a term which stands for the time of operation in the "still picture" mode until noise appears.

The microrelief was measured using a SMM-2000T scanning tunneling microscope produced by the KPD Co. Ltd., Moscow. STM images shown below are typical for a series of samples prepared and tested in different experiments. An average roughness of the surface was determined as the mean of ten profile amplitudes taken in different places of the image.

\section{RESULTS AND DISCUSSION}

Considering that the surface relief of thin coatings is largely determined by the substrate surface relief, the primary task was to produce substrates with a minimum roughness. Figure la shows a typical STM image of the working surface of a bare video head after the final
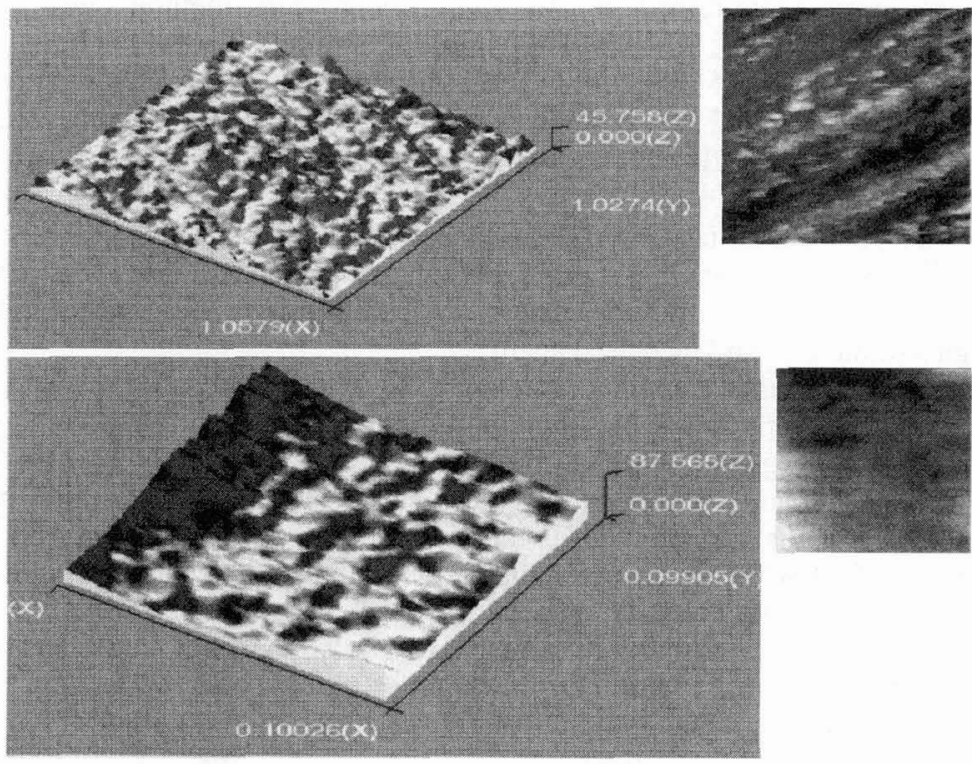

$\mathbf{a}$

Fig. 1. Typical STM images of working surface of a bare video head : $\mathrm{a}$ - after final machining; $\mathrm{b}$ - after etching with argon ions 
machining.

Characteristic traces of polishing are seen on the surface. An average roughness of the surface is $10-20 \mathrm{~nm}$.

To smooth off irregularities, the video head surface was etched with argon ions having an energy of about $1 \mathrm{keV}$. Properly selecting the etching time, we managed to decrease the irregularities on the average to $3-5 \mathrm{~nm}$ (Fig. 1b).

The surface roughness of DLC deposited on such video heads proves to be higher, of the order of 5-10 nm, owing to the domain structure of the film (Fig. 2a), but can be lowered by bombardment with argon, oxygen or nitrogen ions. As distinct from the data [7] for thicker coatings, the optimal treatment time is several minutes. Figure $2 b$ shows a characteristic section of a DLC after etching with $1 \mathrm{keV}$ oxygen ions for 5 minutes. The
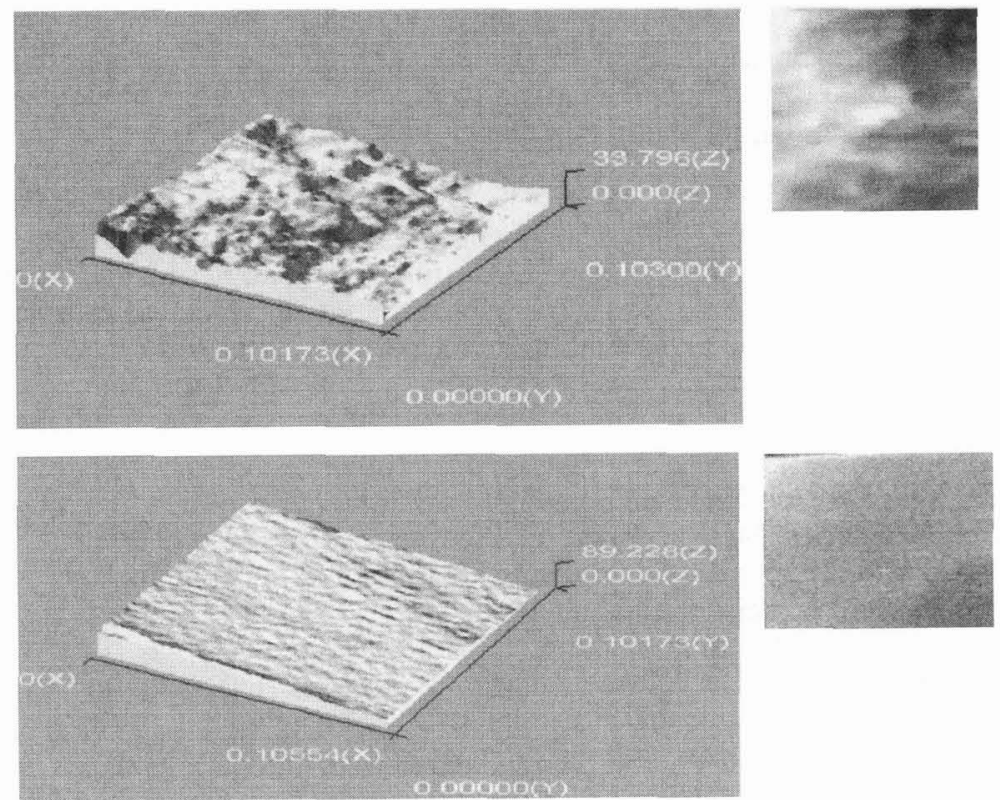

\section{$\mathbf{a}$}

Fig. 2. Typical STM images of working surface of a video head coated with DIC:

$a$ - as deposited; $b$ - after etching with oxygen ions

average roughness is $1.5-3 \mathrm{~nm}$.

Friction coefficients of thin DLC on steel versus duration of etching with oxygen ions are given in Fig. 3. It can be seen that at the etching time of 2-5 minutes the friction coefficient is nearly twice as low as the initial value. If the etching time is longer, the friction coefficient tends to increase.

Wear resistance data of video heads coated with DLC are presented in the Table. 


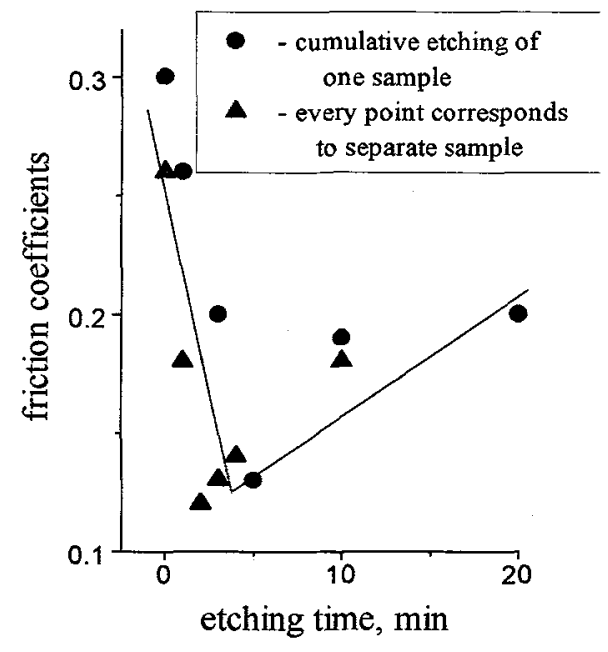

Fig. 3. Friction coefficients of thin DLC's on steel vs duration of etching with oxygen ions
TABLE. Wear resistance of video heads coated with DLC

\begin{tabular}{|c|c|c|c|}
\hline Sample & $\begin{array}{c}\text { Treatment } \\
\text { of } \\
\text { DLCsurface }\end{array}$ & $\begin{array}{c}\text { Wear resistance } \\
\text { (\% of initial } \\
\text { level) }\end{array}$ & $\begin{array}{c}\text { Clogging } \\
\text { time (s) }\end{array}$ \\
\hline $\begin{array}{c}\text { bare } \\
\text { head }\end{array}$ & - & 16 & 44 \\
1 & as deposited & 60 & 40 \\
2 & ion etched & 58 & $>300$ \\
3 & ion etched & 60 & $>300$ \\
4 & ion etched & 52 & $>300$ \\
5 & ion etched & 52 & $>300$ \\
\hline
\end{tabular}

As is seen from the Table, DLC whose thickness is only several tens of nanometers considerably improve wear resistance of the video heads. The stability of the "still picture" image due to ion etching of DLC surface is sharply increased, too (the stability is usually impaired as a result of accumulation of magnetic tape wear products on the working surface of video heads).

\section{References}

[1]. A. Grill, and V. Patel, Diamond Relat. Mater., 2 (1993) 597-605.

[2]. K. Enke, H.Dimigen and H. Hubsch, Appl. Phys. Lett. 36 (1980) 291-293

[3]. C. Weissmantel, K. Bewilogua, K. Breuer, D. Dietrich, U. Ebersbach, H. J. Erler, B. Rau and G. Reisse, Thin Solid Films, 96 (1982) 31-35

[4]. K. Enke, Thin Solid Films, 80 (1981) 227-231

[5]. K. Miyoshi, R. L. C. Wu, A. Garsadden, P. N. Barnes and H. E. Jackson, J. Appl. Phys., 74 (1993) 4446-4454.

[6]. A. I. Maslov, G. K. Dmitriev, and Yu. D. Chistyakov, Prib. Tekh. Eksp. 3 (1985) 146-149.

[7]. I. Sh. Trakhtenberg, S. A. Plotnikov, O. M. Bakunin, S. G. Yakovleva, A. A. Nechaev, S. D. Gorpinchenko, A. B. Vladimirov, L. G. Korshunov, N. V. Gavrilov, and V. N. Mizgulin, Diamond Relat. Mater., 4 (1995) 1020-1024. 